selected East African ethnic groups. The questionnaire is in two parts: Part A referring to basic characteristics of the people investigated, and Part B consisting of a further section covering the following topics: I. The introduction of family planning and other innovations; II. Traditional customs, practices, and beliefs influencing fertility; III. The woman's role; IV. The man's role; V. Relationships between the sexes: marriage, children; VI. Rules of politeness, communication, and language. It is intended that contributions obtained as a result of the questionnaire shall be published by the Institute of African Studies, University of Nairobi, as a source book for persons preparing training and information materials to motivate East African peoples towards the adoption of modern family-planning practices.

\title{
African Regional Population Conference, Accra, December I97I
}

THE International Union for the Scientific Study of Population and the United Nations Economic Commission for Africa will hold a Regional Conference on Population in African Development (PAD) in co-operation with the International Planned Parenthood Federation (IPPF), from 9 to 18 December 1971 , in Accra, Ghana. The main theme will be the contribution of demography in raising the standard of life of the African peoples. The programme is arranged to give opportunities for a comprehensive review of population characteristics, prospects, and policies in the region and of ways in which the increasing knowledge and understanding can best be used in development planning. There will also be group meetings on special topics of demographic methodology. The main topics at the plenary sessions will be: population prospects in Africa; demographic data collection; analysis and presentation of demographic data for the use of planners and administrators; application of demography in planning for social and economic development; population policy and programmes; and demographic training and research.

Inquiries should be addressed to the Executive Secretary, Dr. Bruno Remiche, I.U.S.S.P., 2 rue Charles Nagette, Liège, Belgium.

\section{ECA (Economic Commission for Africa) Rural Development Conference at Accra}

A MEETING of experts on the development of rural life and institutions in West Africa was held at Accra from 22 to 3 I July 1970, organized by the ECA in co-operation with the Regional Inter-Agency Committee on Rural Development in Africa (whose members are FAO, ILO, WHO, UNICEF, UNESCO, UNHCR, and UNDP), with the assistance of the government of Ghana. The meeting was attended by senior technical experts representing Liberia, Sierra Leone, Mali, Niger, Mauritania, Ghana, Nigeria, and Dahomey as well as observers from the above mentioned international organizations, the OAU and CAFRAD (Centre Africain de Formation et de Recherche Administrative pour le Développement).

Three broad issues were discussed: (a) problems encountered by member states in the West African sub-region in their respective efforts to promote the development of active rural life and rural institutions; (b) exchange of ideas on the planning, organization, financing, and execution of rural development programmes in the countries of the sub-region; and (c) means of securing the co-operation and agreement of member governments in the sub-region for the adoption of an integrated approach to their rural development programmes. The participants recommended the collaboration of the ECA with other international organizations on this project and defined a possible field of activity for CAFRAD concerning training of senior staff for rural development.

$$
\text { (Abridged from } C A F R A D \text { News, No. 8, Dec. 1970.) }
$$

